\title{
Tax policy and firms' financing decisions: empirical evidence from the Dominican Republic
}

\author{
ALESSANDRA AMENDOLA \\ University of Salerno \\ Dept. of Economics and Statistics \\ Via Giovanni Paolo II 132, Fisciano (SA) \\ ITALY \\ MARINELLA BOCCIA \\ University of Salerno \\ Dept. of Economics and Statistics \\ Via Giovanni Paolo II 132, Fisciano (SA) \\ ITALY
}

\author{
GIANLUCA MELE \\ World Bank, \\ Washington, \\ USA
}

\author{
LUCA SENSINI \\ University of Salerno \\ Dept. of Management and Inn. Systems \\ Via Giovanni Paolo II 132, Fisciano (SA) \\ ITALY
}

\begin{abstract}
Numerous studies have tried to explain the financial behaviour of firms based on different theories. Despite the vast and rich literature, only in the last decade has attention also been focused on emerging economies. In the first place, the purpose of this paper is to investigate the determinants of the capital structure in an emerging economy, such as that of the Dominican Republic, testing the sustainability of the trade-off and pecking order theories. Secondly, we also investigated the impact of tax policy on the financial behaviour of businesses. In this perspective, this study overcomes the distorting problems associated with estimating the tax variable, as it uses data from each company's tax returns. The data were provided by the Ministry of Finance to the World Bank as part of a collaboration on the analysis of fiscal policy. A fixed-effects (FE) estimation technique has been employed to analyse the financial structure of companies. Overall, the results show that the individual determinants have a strong ability to explain the capital structure of companies, also highlighting that, in some cases, the fiscal variable influences the financial behaviour of companies.
\end{abstract}

Key-${ }^{-}$Words: Capital structure, Financial Decisions, Emerging countries, Fixed Effect.

Received: September 25, 2020. Revised: April 1, 2021. Accepted: April 12, 2021. Published: April 21, 2021.

\section{Introduction}

Starting from the pioneering research studies in $[1,2]$, numerous works have tried to explain the financial behaviour of firms. The heated debate that has matured in the literature over the last sixty years has led to the development of some important theories that, based on a series of variables, have tried to explain the different financial decisions of companies in an attempt to identify the best combination between equity and debt. In this perspective, the trade-off theory [3], the pecking order theory $[4,5]$, the theory of agency costs [6], the theory of market timing [79] and the theory of stock returns [10] are those that have received the most support. These theories provide an important starting point for understanding corporate financing decisions and explaining what fundamental determinants of the capital structure are. However, despite the large and rich literature available on this topic, the empirical results deriving from the application of each of these theories have shown conflicting results. This circumstance also depends on the fact that the capital structure of a company is influenced by the specific characteristics of the firm and by the reference economic context [1113]. Therefore, these factors can have an important explanatory capacity in explaining the capital structure of firms and, at the same time, in understanding the different results obtained in the various countries analysed.

Within the context briefly outlined, first and foremost this paper aims to investigate the determinants of the capital structure in an emerging economy, such as that of the Dominican Republic.

Namely, based on the trade-off theory and the pecking order theory, we used the leading determinants suggested by the literature to explain the financial behaviour of firms (size, profitability, assets structure, growth) [see among others 12 28]. In this regard, the literature [14] has suggested that the legal, institutional and cultural structure of emerging economies is significantly different than that of developed markets [15]. This has recently incised the attention of the literature concerning the capital structure in emerging economies [29- 
35]. In this regard, the financial behaviour of firms in these countries is still an open issue capable of providing further and useful empirical evidence on the sustainability of the various theories.

Secondly, given that the Dominican Republic has introduced a series of tax incentives to favour the establishment and development of businesses, the analysis also investigates the impact of tax policy on the financial behaviour of businesses, comparing the capital structure of the companies benefiting from the tax incentives with that of the non-beneficiary companies.

Although most empirical studies have found a positive association between taxation and financial leverage, the results are often discordant, also due to the different methods used to estimate the tax effect on the capital structure. A common problem of most of these studies is that the measures of the tax rate was often based on balance sheets information and not consider the companies' actual tax returns. Consequently, given that very often significant differences are generated between accounting and tax income, it is possible that the results suggest misleading conclusions on the above relationship.

To solve these problems, it would therefore be necessary to use direct information on the corporate tax returns to avoid estimation bias and significantly reduce the risk of error in the estimates. However, the tax returns contain confidential information and, therefore, these data are hardly made public or provided to scholars. Accordingly, studies that have investigated the tax impact on the capital structure using the tax returns of individual companies are quite rare.

Given the above, the present study is characterized by investigating the effects of tax policy on the capital structure of companies in the Dominican Republic, using data from the tax returns of each company. Consequently, this study is based on reliable and official data, eliminating the problems associated with estimating the tax variable.

The data cover the period 2012-2015 and were provided by the Ministry of Finance to the World Bank as part of a collaboration on the analysis of current fiscal policy.

Moreover, the analysis also highlights the impact of the fiscal incentive policy on the financial behaviour of companies, providing useful information to the economic and political actors of the Dominican Republic. In that light, this analysis is one of the few directly based on the tax returns of individual companies providing further empirical evidence helpful to the intense debate on the relationship between taxation and capital structure.

The paper is organized as follows. Section 2 reports the review of the relevant literature, illustrates the main determinants of the capital structure and presents the research hypotheses. The Taxation System in the Dominican Republic and the preliminary description of the data set is illustrated in Section 3. Section 4 and 5 provide details on the quantitative techniques and methodology. Section 6 reports the reached empirical results and provides some comments. Finally, Section 7 illustrates concluding remarks.

\section{Literature Review and Research Hypotheses}

The papers $[1,2]$ represent the cornerstone of modern finance [16] and have provided the basis for the broad and intense debate on the structure of capital. In a perfect market, the two authors first suggested that financial decisions are irrelevant to the determination of firm value. Subsequently, the same authors highlighted that, in the presence of corporate taxes, the value of the company can be increased by maximizing the debt. However, as amply pointed out by subsequent literature, the theories of Modigliani and Miller find little application in the real world, as markets are imperfect. Although more than sixty years have passed since the authors' first pioneering paper, the debate remains open and the question unresolved [17].

Among the main theories developed by the literature, the ones that seem to adapt best to the context of reference object of our investigation are the theory of the trade-off and that of the pecking order.

The trade-off theory [3], taking up the approach of Modigliani and Miller, assumes that there is an optimal capital structure for each firm and is based on three fundamental elements: tax shields, bankruptcy costs and agency costs [13]. In this perspective, the financial decisions of companies are aimed at achieving an optimal debt ratio, in which the tax benefits deriving from the greater debt can offset the greater costs and risks of financial difficulties $[18,19]$.

Consequently, under certain conditions, leverage is advantageous and companies prefer to use debt even if they have internal funds. Therefore, the capital structure of firms converges towards an industry average (static trade-off) or shifts within acceptable limits (dynamic trade-off).

The pecking order theory $[4,5]$ does not hypothesize an optimal capital structure but suggests that firms' financing decisions follow a hierarchical order of preference based on the lowest level of information asymmetry between 
firm and investors. In this perspective, to finance investments, companies prefer to use internal funds as long as they are sufficient. Only in the event of a financial deficit, companies will resort to sources of external financing, preferring debt first and, ultimately, equity $[36,37]$.

Thus, equity financing is the ultimate source of financing because of the information asymmetry problem and not because of the cost of issuing [4].

These two theories have paved the way for numerous empirical researches that have tested the validity of the two different approaches in various economic contexts. The results, as widely documented by the literature on the subject, are however conflicting [38-46; among others].

For this study, we followed the theoretical approach of these theories, believing that this setting can better explain the financial behaviour of companies in an emerging economy, such as the Dominican one. Furthermore, the two approaches are complementary and do not conflict, so they can be used together.

In this perspective, following a consolidated empirical literature $[12,19-28,44]$, we investigated the determinants of the capital structure of firms (Total Debt, Long-Term Debt and Short Term Debt) using some firm-specific factors, such as size, profitability, assets tangibility, and growth.

These factors showed a significant relationship with the level of corporate debt and have been widely used by empirical research to investigate the financial behaviour of firms.

Besides, we explore also the role of Fiscal benefits, both considering this as a further determinants of capital structure and discriminate between firms that receive and do not receive the incentive.

\subsection{Size and Capital Structure}

The size of a firm is considered a relevant factor in explaining the structure of capital and therefore is used as a proxy to explain the financial behaviour of firms [38, 39, 47-50].

In this regard, both theories considered suggest a positive relationship between the size and debt of the firm. In fact, the larger size reduces the information asymmetry between the company and potential capital lenders. Therefore, larger companies are favoured in accessing credit [48] and may benefit from a lower cost than smaller companies, as they have a better reputation in the market and are more transparent $[38,51]$. On the other hand, in smaller firms, the information asymmetry increases and therefore leads to higher bankruptcy costs [52,53]. In this perspective, the size represents an inverse proxy of the probability of financial difficulties [38].

The literature has amply highlighted that the high information asymmetry [54] and the high transaction costs can significantly influence the financial behaviour of these firms, increasing credit constraints and the probability of bankruptcy [55-57].

Consequently, the smaller size favours the use of short-term debt, while making access to medium and long-term debt more complex.

Therefore, we can formulate the following research hypotheses:

Hla - The size of the firm is positively correlated to the total debt.

$H 1 b$ - The size of the firm is positively correlated to medium and long-term debt.

HIc - The size of the firm is negatively correlated with short-term debt.

\subsection{Profitability and Capital Structure}

The relationship between profitability and the capital structure it is quite controversial and has produced mixed results $[26,38,38,41]$.

In particular, the trade-off theory argues that there is a positive relationship between profitability and debt, as profitable firms have a greater ability to attract external financing [51], they have a lower probability of failure [42] and prefer to go into debt to take advantage of tax shields $[2,44]$.

Conversely, the pecking order theory suggests a negative relationship between profitability and debt, as profitable firms can self-finance and therefore prefer to use internal funds and, only if necessary, external funds [40, 65-70].

Following the assumptions of the pecking order theory, our research hypotheses are as follows:

H2a - Profitability is negatively correlated with total debt.

$H 2 b$ - Profitability is negatively correlated with medium and long-term debt.

H2c - Profitability is negatively correlated with short-term debt.

\subsection{Assets Tangibility and Capital Structure}

Both theories suggest a positive relationship between tangible assets and the capital structure. In particular, the trade-off theory has shown that 
tangible assets favor the granting of external financing [26,48], as they can be used as collateral, reducing risks for lenders $[18,38,38$, 42- 44,]. In this perspective, the use of tangible assets as collateral plays a fundamental role in emerging economies, where creditors' protection mechanisms are generally weaker than in more developed economies [64]. In line with what has been highlighted, the Pecking Order theory also suggests a positive relationship between tangible assets and debt, as the presence of collateral reduces the costs of borrowing and the problems of information asymmetry.

Therefore, in agreement with both theories, our research hypotheses are as follows:

\section{H3a - Assets tangibility is positively correlated with the total debts;}

$H 3 b$ - Assets tangibility is positively correlated with medium and long-term debt.

$\mathrm{H} 3 \mathrm{c}$ - Assets tangibility is positively correlated with short-term debt.

\subsection{Growth and Capital Structure}

The relationship between growth and capital structure is divergent between the two theories. According to the trade-off theory, growth has a negative relationship with debt [6]. Growing firms prefer not to contract debt because of the higher financing costs and the possible costs associated with possible financial difficulties [39].

Conversely, according to the pecking order theory, growth has a positive relationship with debt. Businesses they prefer to finance growth first with retained earnings and then, in hierarchical order, with low-risk debt, high-risk debt and, finally, with new equity [4]. However, the relationship between debt growth and maturity has produced conflicting results $[24,50$, 61].

Based on the foregoing, following the pecking order theory, our research hypotheses are the following:

$\mathrm{H} 4 \mathrm{a}$ - Growth is positively correlated with total debt.

$H 4 b$ - Growth is positively correlated to medium and long-term debt;
H4c - Growth is positively correlated with shortterm debt.

\section{Fiscal Incentives and Corporate Income Tax}

In order to test the research hypothesis formulated in the previous section, this study analyzes the financial behaviour of companies headquartered in the Dominican Republic (DR), focusing the attention on the main determinants that influence the financial decisions of companies and, at the same time, on the effect that the current tax incentive system produces on the financial behaviour of companies.

For the sake of completeness, a brief description of the tax and incentive system currently in force in the DR is reported in the following. Taxation in DR is governed by the Tax Code, introduced with Law no. 11-92 of May 31, and its subsequent amendments. The law is essentially based on the principle of territoriality. Therefore, all income produced within the DR is subject to taxation. Fiscal and tax incentives can be generated by various concessions that can be granted to companies, to promote different development objectives [65].

In the specific context of the DR, the main tax incentives concern subsidies on Value-Added Tax (VAT) and those on Corporate Income Tax (CIT). The incentives provide for exemptions and tax credits and are granted to companies located in special economic zones (SEZ), tourism development groups, new businesses, companies located in border regions and other economic activities specifically identified by legislation tax.

In summary, the purposes for which the concessions are granted can be divided into two categories: tax concessions granted to incentivize investments (tax incentives), and concessions granted for territorial, social and welfare development purposes. Determining tax benefits is quite complex and is influenced by different variables, such as the sector to which it belongs, the region, etc. Therefore, depending on the case, the benefits may have different rates and durations.

Given the multiplicity of variables that affect the determination of the tax burden and the granting of incentives, the estimate of the incidence of the fiscal variable on the financial behaviour of companies would be rather uncertain and unreliable. Therefore, this paper uses data from companies' tax returns. This approach makes it possible to base the survey on actual tax benefits, highlighting the real impact they have on the financial behaviour of companies.

On average, in the period 2002-2015, the revenues deriving from the application of the CIT, which 
has a rate of $27 \%$, represented about $20 \%$ of the total tax revenue and $1.6 \%$ of GDP [66].

This circumstance is also attributable to the aggressive fiscal policy undertaken by most Caribbean countries to attract and encourage foreign investments. Over the past thirty years, the largest countries are the ones that have reduced the CIT rate the most [71-75].

However, the tax expenses incurred by the DR to pursue its economic development objectives and to incentivize businesses have far exceeded $6 \%$ of GDP.

A much higher percentage than other countries that have economic characteristics comparable to DR [59]. Consequently, the Dominican Republic is reviewing fiscal policy, to reduce the impact of tax expenditure on GDP and limit the effects it has on the economy.

Regarding the Dominican Republic, some previous research has studied the effects of VAT and CIT tax breaks on investments and growth. Otherwise, no study has investigated the impact of tax effects on the capital structure of companies. In the present study, this goal is achieved by the availability of an anonymized data set provided by the Dominican Republic Ministry of Finance to the World Bank was analyzed. This allows having access to a large and confidential data set containing all the information of the companies based in the DR still preserve the possibility to match the single records with the company name. Tax returns include the period from 2012 to 2015 .

\section{Methodology and Variable of Interest}

In the evaluation of public policies and programs, the approach represented by "true" or "natural" experiments based on random assignments it is generally considered one of the most useful ways for analyzing causal relationships [76].

However, in the context of the present analysis, treated and non-treated enterprises often differ in many respects that may affect the results of the analysis (i.e. selection biases). Therefore, in order to evaluate the program and given the lack of an experimental design, an alternative approach have to be adopted such as a quasi-experimental approach that compares the results between the treatment and the control groups, while bearing

${ }^{1}$ In this model (FE) it is assumed that the intercept is deterministic and varies from individual to individual, or for individual and over time. See also section 5.2 for a discussion about the choice of this model.

2 In most Econometric application, a FE structure does in mind that not all the treatments are randomly assigned. Due to the need of controlling for unobserved heterogeneity and given the panel structure of the data, this paper examines the effects of tax incentives on firm capital structure indicators by employing fixed-effects (FE) 1 estimation techniques considering both firms and time fixed effects 2 .

This heterogeneity can be removed from the data by detracting the group-level average over time, or by considering a first difference which will eliminate any time invariant factors of the model. The assumptions about the individual specific effect are the random effects (RE) and the fixed effects (FE) assumption. As to the RE assumption the individual-specific effects are uncorrelated with the independent variables, while in the FE assumption the individual-specific effects are correlated with the independent variables.

If the random effects assumption is valid, the random effects estimator is more efficient than the fixed effects estimator. However, if this assumption is not supported, the RE estimator is not consistent. The choice between these two models is made employing the Durbin-WuHausman test (see section 5.2 and footnote 2 ).

Following what highlighted in section 2, among the whole set of available information, we have identified three dependent variables selected as indicators of the corporate capital structure: Total Debt (TD), Medium and Long-term Debt (MLD)and Short-Term debt (STD).

As for the selection of the independent covariates among the available information provided by the Ministry, the main theoretical and empirical evidence provided by the prevailing literature on the corporate capital structure have been taking into account $[19,22,24,28,44,59-61,63,68-70$, to cite a few]. The independent variables selected are the following: size, profitability, assets tangibility and growth. More in details, among them, in order to collect more information, we use two variables to explain the profitability and two variables related the growth rate. The final variables included in the analysis, and their measures, are summarized in Table 1. Furthermore, in order to investigate the effect of fiscal incentives policy, we include a dummy variable, TAX, indicating whether the firm receives or not Tax incentives. 
Table 1 - Variables of interest

\begin{tabular}{lll}
\hline ID & \multicolumn{1}{c}{ Name } & \multicolumn{1}{c}{ Measure } \\
\hline TDti,t & Total debt & Total Liabilities/Total Assets \\
MLDi,t & Medium and long-term debt & Non-current Liabilities/Total Assets \\
& & \\
STDi,t & Short-term debt & Current Liabilities/Total Assets \\
& & Independent Variables \\
\hline TAX & Incentives & Dummy $=1$ if firm receives the incentive \\
SIZEi,t & Size & Logarithm of Total Assets \\
PROFi,t & Profitability & EBIT/Total Assets \\
ROE & Profitability & EBIT/Net Assets \\
TASi,t & Tangibility Asset & Tangible Assets/Total Assets \\
GROWi,t TA & Growth Total Assets & (Total Assetsi,t - Total Assetsi,t-1)/T. Assetsi,t-1 \\
GROWi,t SAL & Growth Sales & (Total Salesi,t - Total Salesi,t-1)/Total Salesi,t-1 \\
\hline & &
\end{tabular}

This additional independent variable also allows us to compare the financial behavior of those companies that received the incentives with that of the companies that did not benefit from the incentives. This indicator variable, TAX, that allows to discriminate for the effects of the fiscal policy, represents a relevant independent variable in the first equation which is estimated considering the full sample. To further investigate on the effect of the treatments on the capital structure, the analysis has also been computed on the two separate clusters of firms (with incentives vs without) as specified in the second equation.

Namely, the following equations are estimated for each of the three considered dependent variables using the whole sample information, equation (1), and the two-separate subsample, equation (2):

$$
\begin{gathered}
Y_{i t}=\operatorname{Tax}_{i t}+a \boldsymbol{X}_{i t}+\mu_{i}+u_{t}+e_{i t} \\
Y_{i t}=a \boldsymbol{X}_{i t}+\mu_{i}+u_{t}+e_{i t}
\end{gathered}
$$

Where

- $\quad Y_{i t}$ is a dependent variable for firm $i$ at time $t$.

- $\quad$ Taxit is a dummy variable indicating whether the firm receives Tax incentives, which takes value one if the firm receives the Fiscal Incentive, or zero otherwise.

- $\quad X_{i t}$ is a vector of $k$ firm-level explanatory.

- $\quad \mu_{i}$ represents unobserved heterogeneity due to firm-level differences in efficiency and managerial skill.

- $u_{t}$ represents time specific fixed effects

- $\quad e_{i t}$ is an error term assumed to be independently and identically distributed with a mean of zero and a variance of $\sigma^{2}$ 


\section{Empirical Analysis}

As a first step, we have extracted from the Ministry data set a panel of full information. To this purpose, we have excluded from the analysis companies with zero Net Assets value. The datasets were also pre-cleaned to avoid the effect of outliers. About 32.000 companies were included in the final sample observed for the 4-year time period, 2012-2015. The main characteristics of the data have been investigated in a preliminary analysis computed on the entire sample and on the two separate sub-sample of firms (with incentives and without). The same has been done for the fixed effect panel regressions.

\subsection{Preliminary Analysis}

Table 2 reports the main statistics (Mean, Standard Deviation, Minimum and Maximum) that help us to describe, summarize and show the data, even if these did not help us to reach conclusions about the model. These are computed on the total sample of considered firms for the three dependent variables analyzed (TD. MLD and STD), the $k=6$ explanatory variables SIZE, PROF, ROE, TAS, GROWTH TA, GROWTH SAL and the dummy variables TAX. The same statistics are then computed considering the two groups separately as reported in Tables 3 and 4. As the tables show looking at the total observations the number of beneficiaries firms is lower than the no beneficiaries and consequently the descriptive statistics results are. In the most of cases- affected by sample size.

Table 2: Summary statistics of dependent and independent variables -Total sample

\begin{tabular}{|c|c|c|c|c|c|}
\hline Variable & Obs & Mean & Std. Dev. & Min & Max \\
\hline TD & 126,816 & .6793006 & 175.726 & 0 & 5.675 .172 \\
\hline MLD & 126,816 & .0639408 & 160.519 & 0 & 5.666 .556 \\
\hline STD & 126,816 & .6153599 & .7294321 & 0 & 1.282 .841 \\
\hline TAX & 126,816 & .332876 & .4712444 & 0 & 1 \\
\hline SIZE & 126,816 & 1.512 .782 & 2.157 .869 & -460.517 & 2.516 .115 \\
\hline PROF & 126,816 & 635167.4 & $4.19 \mathrm{e}+08$ & $-1.47 \mathrm{e}+11$ & $1.10 \mathrm{e}+10$ \\
\hline $\mathrm{ROE}$ & 126,816 & -.1963773 & 3.130 .819 & -6.500 .951 & 7.994 .728 \\
\hline TAS & 126,816 & $-3.33 e+07$ & $3.85 \mathrm{e}+08$ & $-3.77 e+10$ & $2.09 \mathrm{e}+10$ \\
\hline GROW TA & 126,816 & $7.35 \mathrm{e}+07$ & $7.90 \mathrm{e}+08$ & -.99 & $8.46 \mathrm{e}+10$ \\
\hline GROW SAL & 126,816 & $7.43 \mathrm{e}+07$ & $9.02 \mathrm{e}+08$ & -.99 & $1.16 \mathrm{e}+11$ \\
\hline
\end{tabular}


Table 3: Summary statistics of dependent and independent variables -Enterprises with Incentives

\begin{tabular}{|c|c|c|c|c|c|}
\hline Variable & Obs & Mean & Std. Dev. & Min & Max \\
\hline TD & 42,214 & .9762222 & 294.865 & 0 & 5.675 .172 \\
\hline MLD & 42,214 & .0913652 & 2.772 .664 & 0 & 5.666 .556 \\
\hline STD & 42,214 & .8848571 & 1.028 .209 & 0 & 1.282 .841 \\
\hline SIZE & 42,214 & 1.465 .459 & 2.268 .356 & -460.517 & 2.433 .459 \\
\hline PROF & 42,214 & -2521547 & $7.41 \mathrm{e}+07$ & $-7.42 \mathrm{e}+09$ & $1.81 \mathrm{e}+09$ \\
\hline ROE & 42,214 & -.9386049 & 5.299 .487 & -6.500 .951 & 7.823 .931 \\
\hline TAS & 42,214 & $-3.27 e+07$ & $4.41 \mathrm{e}+08$ & $-3.65 e+10$ & $5.08 \mathrm{e}+09$ \\
\hline GROW TA & 42,214 & $7.29 \mathrm{e}+07$ & $6.72 \mathrm{e}+08$ & -.99 & $3.70 \mathrm{e}+10$ \\
\hline GROW SAL & 42,214 & $4.13 \mathrm{e}+07$ & $4.76 \mathrm{e}+08$ & -.99 & $2.82 \mathrm{e}+10$ \\
\hline
\end{tabular}

Table 4: Summary statistics of dependent and independent variables -Enterprises without Incentives

\begin{tabular}{|c|c|c|c|c|c|}
\hline Variable & Obs & Mean & Std. Dev. & Min & Max \\
\hline TD & 84,602 & .5311452 & .4738903 & 0 & 4.741 .294 \\
\hline MLD & 84,602 & .0502568 & .1608599 & 0 & 7.873 .175 \\
\hline STD & 84,602 & .4808884 & .4644635 & 0 & 4.714 .781 \\
\hline SIZE & 84,602 & 1.536 .395 & 2.060 .324 & 460.517 & 2.516 .115 \\
\hline PROF & 84,602 & 2210278 & $5.10 \mathrm{e}+08$ & $-1.47 \mathrm{e}+11$ & $1.10 \mathrm{e}+10$ \\
\hline ROE & 84,602 & .1739732 & 821.988 & -991.81 & 7.994 .728 \\
\hline TAS & 84,602 & $-3.36 e+07$ & $3.53 \mathrm{e}+08$ & $-3.77 e+10$ & $2.09 \mathrm{e}+10$ \\
\hline GROW TA & 84,602 & $7.37 \mathrm{e}+07$ & $8.36 \mathrm{e}+08$ & 1399 & $8.46 \mathrm{e}+10$ \\
\hline GROW SAL & 84,602 & $8.89 \mathrm{e}+07$ & $1.04 \mathrm{e}+09$ & -.9 & $1.16 \mathrm{e}+11$ \\
\hline
\end{tabular}




\subsection{Estimation Results and Discussion}

As described in section 4, we used fixed effect estimation techniques to assess the impact of tax incentives on the capital structure.

In order to justify the choice of Fixed Effects (FE), two specification test are performed. The first one is Ramsey's Test [77] where the null hypothesis considers that the data are not affected by omitted variables problems. Rejecting the null hypothesis ( $\mathrm{p}<0.05$ for a $5 \%$ test $)$ means that a more complex structure than the OLS is required to capture the variability that affects the dependent variable due to the omitted variables.

The second test considered is the Hausman Test [78] which detects endogenous regressors. Rejecting the null hypothesis ( $p$ $<0.05$ for a $5 \%$ test) allows us to assert that the difference in the coefficients of panel analysis is systematic (i.e. the model is characterized by fixed effects).

The two specification tests have been computed for the three considered samples, the full sample the sample of firms which have beneficiated of the incentives and the sample of firms without. The results are reported in Table 6.

Both the test gives results supporting the choice to use fixed effect estimation technique in compute our panel regression analysis. Therefore, we estimate the equation (1) on the full sample data set and equation (2) on both the sample with and without the incentives. The estimation results have been synthetized in the following tables. Namely, Table 7 concerns the results estimated considering the full observed sample; Table 8 , reports the results related to the enterprises benefiting from the incentives and Table 9 the enterprises not benefiting of it.

Overall, the results of our analysis offer some interesting results on the financial behavior of companies in the Dominican Republic, also highlighting the impact of the fiscal variable on each of the different determinants. We interpret and add comment to the results considering the sign and statistical significance of each variable on all the kind of debt exanimated and, as
Marinella Boccia, Gianluca Mele, Luca Sensini above said, diving the sample. The results sometimes are in line with the TO, sometimes with the PO theory. In line with the literature, the fiscal benefits produce a significant and positive effect on total debt and short-term debt (Table 7) with high statistical significance, also producing a different impact on the individual determinants of the capital structure. This impact is highlighted below for each variable and can be deduced from the subdivision of the sample into the two clusters of companies (with incentives, Table 8; without incentives, Table 9). Size does not have a statistically significant impact on the financial behavior of the entire sample. However, the size produces a different effect depending on whether or not companies benefit from the fiscal incentives. In particular, for firms benefiting from tax incentives, size has a significant negative effect on TD and STD (Table 8). These results show that larger companies, benefiting from tax incentives, use internal resources to finance investments and are therefore less indebted. Conversely, for firms that do not benefit from tax incentives, size has a positive and significant effect on TD, MLD and STD (Table 9). These results suggest that larger firms have easier access to credit and prefer to use debt to finance their investments in fixed and working capital [in line with 19, $28,50,60 ; 61,63$, among others] and are consistent with those found in other emerging countries [79-81]. Therefore, the research hypotheses $\mathrm{H} 1 \mathrm{a}, \mathrm{H} 1 \mathrm{~b}$ and $\mathrm{H} 1 \mathrm{c}$ are verified referring to the companies that do not benefit from the incentive, while they must be rejected for the companies benefiting from the incentive.

Regarding the entire sample, the first profitability measure - PROF - has a positive and very significant impact only on TD and MLD, while ROE has a positive effect on all three debt variables (Table 7). These results are consistent with the trade-off theory [39; $42 ; 44 ; 51]$, but they do not confirm our research hypotheses, formulated based on the pecking order theory. Empirical findings are not affected by the tax variable. ROE, in companies that benefit from tax incentives (Table 8), and PROF, in non-beneficiary 
WSEAS TRANSACTIONS on BUSINESS and ECONOMICS DOI: 10.37394/23207.2021.18.71

companies (Table 9), have a positive and significant effect on debt. These results take on particular significance in an emerging economy, due to the limited development of financial markets and a system mainly focused on bank lending. In this perspective, profitability represents a fundamental element to ensure economic and financial equilibrium in the short and med-long term. Empirical findings are consistent with some of the literature [82-84], but diverge from those found by other scholars, helping to further fuel the controversial debate between profitability and financial behavior of firms $[85,86]$. About Assets tangibility, the fiscal variable does not influence the financial behavior of companies: the effect is negative and not significant. Looking at the results for the beneficiary and nonbeneficiary companies, Assets tangibility has a positive and significant effect on medium and long-term debt, in line with both theories analyzed and the prevailing literature $[84,86,87,89]$. In this perspective, the presence of Assets tangibility favors the granting of loans [48], as it reduces the risks for lenders, information asymmetry $[18,38,39,42,44]$ and risk of financial distress [65]. In emerging economies, the use of such assets as collateral plays a fundamental role, as creditors' protection mechanisms are generally weaker than in more developed economies [64]. Assets
Alessandra Amendola, Marinella Boccia, Gianluca Mele, Luca Sensini tangibility, on the other hand, has a negative and significant impact on TD and STD.

In conclusion, the $\mathrm{H} 3 \mathrm{~b}$ hypothesis must be accepted, while the $\mathrm{H} 3 \mathrm{a}$ and $\mathrm{H} 3 \mathrm{c}$ hypotheses must be rejected. Regarding growth, in line with previous researches, the results are conflicting or not significant $[24,50,61,80$, 82].

In companies without tax incentives, empirical findings show that the increase in assets determines a positive and significant effect on MLD, suggesting that these companies finance growth with medium and long-term debt (Table 9). These results are in line with the pecking order theory and confirm our $\mathrm{H} 4 \mathrm{~b}$ hypothesis.

However, the growth in assets and sales have a negative impact on the other debt variables (Table 9), as predicted by the trade off-theory $[6,39]$. Therefore, we must reject hypotheses $\mathrm{H} 4 \mathrm{a}$ and $\mathrm{H} 4 \mathrm{c}$. In other cases, the results are not statistically significant (Table 7 and Table 8).

Finally, the empirical findings reached with the analysis for each of the three different clusters of firms (whole sample, companies with incentives and without incentives) have been summarized in Table 10. The expected sign for each hypothesis has been compared with the sign of the estimated value highlighting the verified hypotheses and the hypothesis that cannot be accepted given the results obtained. 


\begin{tabular}{lllll}
\hline & F & Prob $>$ F & chi2 & Prob $>$ chi2 \\
Total Sample & 356.39 & $(0.0000)$ & 827.88 & $0.0000)$ \\
Firms with incentives & 252.83 & $(0.0000)$ & 74.94 & $(0.0000)$ \\
Firms without incentives & 170.06 & $(0.0000)$ & 132.89 & $(0.0000)$
\end{tabular}

Table 7: Effects of Tax Incentive on TD, MLD, STD - FE estimation - full sample

\begin{tabular}{|c|c|c|c|}
\hline VARIABLES & TD & MLD & STD \\
\hline Tax & $\begin{array}{l}0.170 * * * \\
(0.0499)\end{array}$ & $\begin{array}{c}0.0571 \\
(0.0489)\end{array}$ & $\begin{array}{l}0.113 * * * \\
(0.00728)\end{array}$ \\
\hline SIZE & $\begin{array}{l}-0.00609 \\
(0.00832)\end{array}$ & $\begin{array}{c}0.00307 \\
(0.00591)\end{array}$ & $\begin{array}{l}-0.00916 \\
(0.00686)\end{array}$ \\
\hline PROF & $\begin{array}{c}2.98 \mathrm{e}-12 * * * \\
\quad(5.09 \mathrm{e}-13)\end{array}$ & $\begin{array}{c}3.38 \mathrm{e}-12 * * * \\
(1.99 \mathrm{e}-13)\end{array}$ & $\begin{array}{l}-3.98 \mathrm{e}-13 \\
(5.46 \mathrm{e}-13)\end{array}$ \\
\hline ROE & $\begin{array}{c}0.000533 * * * \\
(0.000176)\end{array}$ & $\begin{array}{l}0.000123 * \\
(6.81 \mathrm{e}-05)\end{array}$ & $\begin{array}{l}0.000410 * \\
(0.000220)\end{array}$ \\
\hline TAS & $\begin{array}{l}-1.20 \mathrm{e}-11 \\
(1.06 \mathrm{e}-11)\end{array}$ & $\begin{array}{r}-3.96 \mathrm{e}-12 \\
(5.20 \mathrm{e}-12)\end{array}$ & $\begin{array}{r}-8.07 \mathrm{e}-12 \\
(1.27 \mathrm{e}-11)\end{array}$ \\
\hline GROW TA & $\begin{array}{l}-4.99 \mathrm{e}-13 \\
(8.68 \mathrm{e}-12)\end{array}$ & $\begin{array}{c}4.54 \mathrm{e}-12 \\
(3.62 \mathrm{e}-12)\end{array}$ & $\begin{array}{l}-5.04 \mathrm{e}-12 \\
(9.44 \mathrm{e}-12)\end{array}$ \\
\hline GROW SAL & $\begin{array}{c}-1.19 \mathrm{e}-12 \\
(1.59 \mathrm{e}-12)\end{array}$ & $\begin{array}{c}-4.39 \mathrm{e}-12 * * * \\
(1.24 \mathrm{e}-12)\end{array}$ & $\begin{array}{c}3.20 \mathrm{e}-12 \\
(2.35 \mathrm{e}-12)\end{array}$ \\
\hline Constant & $\begin{array}{c}0.700 * * * \\
(0.117)\end{array}$ & $\begin{array}{l}-0.00620 \\
(0.0667)\end{array}$ & $\begin{array}{c}0.706 * * * \\
(0.105)\end{array}$ \\
\hline Observations & 77,099 & 77,099 & 77,099 \\
\hline F-test & $\begin{array}{c}6.60 \\
p>F=0.0000\end{array}$ & $\begin{array}{c}0.62 \\
p>F=0.7998\end{array}$ & $\begin{array}{c}203.7 \\
p>F=0.0000\end{array}$ \\
\hline N. of enterprises & 35,869 & 35,869 & 35,869 \\
\hline Method & FE & FE & FE \\
\hline
\end{tabular}

Notes. The treatment variable is the Tax incentive. The independent variables are TAS, PROF, ROE, GROWTH TA, GROWTH SAL and SIZE. Standard errors are reported in round brackets. ${ }^{* *}$ Significant at the 1 percent level. ${ }^{* *}$ Significant at the 5 percent level. ${ }^{*}$ Significant at the 10 percent level. F-tests on the null of zero coefficients and their p-value are also reported. 
Table 8: Determinants of TD, MLD, STD-FE estimation -Enterprises with Incentive

\begin{tabular}{lccc}
\hline VARIABLES & TOTALDEBT & MLD & STD \\
\hline SIZE & $-0.145^{* * *}$ & 0.0285 & $-0.174^{* * *}$ \\
PROF & $(0.0529)$ & $(0.0332)$ & $(0.0242)$ \\
& $-2.88 \mathrm{e}-11$ & $2.18 \mathrm{e}-11$ & $-5.06 \mathrm{e}-11$ \\
ROE & $(5.92 \mathrm{e}-11)$ & $(2.63 \mathrm{e}-11)$ & $(5.62 \mathrm{e}-11)$ \\
& $0.00101^{*}$ & $0.000212^{* *}$ & $0.000801^{*}$ \\
TAS & $(0.000524)$ & $(9.06 \mathrm{e}-05)$ & $(0.000439)$ \\
& $-5.34 \mathrm{e}-11^{* *}$ & $1.46 \mathrm{e}-11 * *$ & $-6.80 \mathrm{e}-11^{* *}$ \\
GROW TA & $(2.39 \mathrm{e}-11)$ & $(6.49 \mathrm{e}-12)$ & $(2.71 \mathrm{e}-11)$ \\
& $-3.27 \mathrm{e}-11$ & $6.94 \mathrm{e}-12$ & $-3.96 \mathrm{e}-11$ \\
GROW SAL & $(2.65 \mathrm{e}-11)$ & $(9.86 \mathrm{e}-12)$ & $(3.07 \mathrm{e}-11)$ \\
& $-6.09 \mathrm{e}-12$ & $5.23 \mathrm{e}-12$ & $-1.13 \mathrm{e}-11$ \\
Constant & $(3.75 \mathrm{e}-11)$ & $(1.10 \mathrm{e}-11)$ & $(3.68 \mathrm{e}-11)$ \\
& $3.180^{* * *}$ & -0.317 & $3.497 * * *$ \\
Observations & $(0.796)$ & $(0.498)$ & $(0.365)$ \\
F-test & 23,604 & 23,604 & 23,604 \\
& 0.37 & 0.01 & 45.5 \\
N. of Enrprises & $\mathrm{p}=0.9186$ & $\mathrm{p}>0.9999$ & $\mathrm{p}>\mathrm{F}=0.0000$ \\
Method & 15,897 & 15,897 & 15,897 \\
\hline
\end{tabular}

Notes. The independent variables are the TAS, PROF, ROE, GROWTH TA, GROWTH SAL and SIZE. Standard errors are reported in round brackets. ${ }^{* * *}$ Significant at the 1 percent level. ${ }^{* *}$ Significant at the 5 percent level. ${ }^{*}$ Significant at the 10 percent level. F-tests on the null of zero coefficients and their p-value are also reported.

Table 9: Determinants of TD, MLD, STD- FE estimation-Enterprises without Incentive

\begin{tabular}{lccc}
\hline VARIABLES & TD & MLD & STD \\
\hline SIZE & $0.0772 * * *$ & $0.0202 * * *$ & $0.0571 * * *$ \\
PROF & $(0.00787)$ & $(0.00147)$ & $(0.00754)$ \\
& $3.93 \mathrm{e}-12 * * *$ & $2.64 \mathrm{e}-12 * * *$ & $1.29 \mathrm{e}-12^{* *}$ \\
ROE & $(4.53 \mathrm{e}-13)$ & $(1.29 \mathrm{e}-13)$ & $(5.02 \mathrm{e}-13)$ \\
& $-0.000382^{*}$ & $-5.55 \mathrm{e}-05$ & $-0.000326^{* * *}$ \\
TAS & $(0.000198)$ & $(0.000183)$ & $(7.51 \mathrm{e}-05)$ \\
& $-4.06 \mathrm{e}-11 * * *$ & $7.73 \mathrm{e}-12 * *$ & $-4.83 \mathrm{e}-11 * * *$ \\
GROW TA & $(1.10 \mathrm{e}-11)$ & $(3.48 \mathrm{e}-12)$ & $(1.27 \mathrm{e}-11)$ \\
& $-2.56 \mathrm{e}-11 * *$ & $1.82 \mathrm{e}-11 * * *$ & $-4.38 \mathrm{e}-11 * * *$ \\
GROW SAL & $(9.78 \mathrm{e}-12)$ & $(2.78 \mathrm{e}-12)$ & $(1.10 \mathrm{e}-11)$ \\
& $-6.55 \mathrm{e}-12 * * *$ & $-3.52 \mathrm{e}-12 * * *$ & $-3.02 \mathrm{e}-12 * * *$ \\
Constant & $(8.97 \mathrm{e}-13)$ & $(6.22 \mathrm{e}-13)$ & $(6.17 \mathrm{e}-13)$ \\
& $-0.660 * * *$ & $-0.260 * * *$ & $-0.400 * * *$ \\
Observations & $(0.123)$ & $(0.0234)$ & $(0.118)$ \\
R-squared & 53,495 & 53,495 & 53,495 \\
N. of enterprises & 0.14 & 0.09 & 0.08 \\
Method & 27,315 & 27,315 & 27,315 \\
\hline
\end{tabular}

Notes. The independent variables are the TAS, PROF, ROE, GROWTH TA, GROWTH SAL and SIZE. Standard errors are reported in parenthesis. ${ }^{* *}$ Significant at the 1 percent level. ${ }^{* *}$ Significant at the 5 percent level. ${ }^{*}$ Significant at the 10 percent level 
Tab. 10 - Comparison of Expect and Estimated Signs

\begin{tabular}{|c|c|c|c|c|c|c|}
\hline Hypothesis & $\begin{array}{r}\text { Independent } \\
\text { Variables }\end{array}$ & $\begin{array}{r}\text { Dependent } \\
\text { Variables }\end{array}$ & $\begin{array}{r}\text { Expected } \\
\text { Sign } \\
\end{array}$ & $\begin{array}{r}\text { Total } \\
\text { sample }\end{array}$ & $\begin{array}{r}\text { With } \\
\text { Incentive } \\
\end{array}$ & $\begin{array}{r}\text { Without } \\
\text { incentive }\end{array}$ \\
\hline H1 & Size & TD & + & $\mathrm{NS}$ & - & + \\
\hline H1a & & LTD & + & NS & NS & + \\
\hline $\mathrm{H} 1 \mathrm{~b}$ & & STD & + & NS & - & + \\
\hline $\mathrm{H} 2$ & Profitability & TD & - & + & $\mathrm{NS} /+$ & $+/+$ \\
\hline $\mathrm{H} 2 \mathrm{a}$ & & LTD & - & + & $\mathrm{NS} /+$ & $+/-$ \\
\hline $\mathrm{H} 2 \mathrm{~b}$ & & STD & - & + & $\mathrm{NS} /+$ & $+/+$ \\
\hline $\mathrm{H} 3$ & Assets Tangibility & TD & + & NS & - & - \\
\hline $\mathrm{H} 3 \mathrm{a}$ & & LTD & + & NS & + & + \\
\hline $\mathrm{H} 3 \mathrm{~b}$ & & STD & + & NS & - & - \\
\hline $\mathrm{H} 4$ & Growth & TD & + & NS/NS & NS/NS & $-/-$ \\
\hline $\mathrm{H} 4 \mathrm{a}$ & & LTD & + & NS/- & $\mathrm{NS} / \mathrm{NS}$ & $+/-$ \\
\hline $\mathrm{H} 4 \mathrm{~b}$ & & STD & + & NS/NS & NS/NS & $-/-$ \\
\hline H5 & Tax & TD & + & + & & \\
\hline H5a & & LTD & + & NS & & \\
\hline $\mathrm{H} 5 \mathrm{~b}$ & & STD & + & + & & \\
\hline
\end{tabular}

\section{Concluding Remarks}

Numerous studies have tried to explain the financial behavior of firms based on the different theories developed over the last sixty years. Despite the vast and rich literature, the empirical results deriving from the application of each of these theories have shown conflicting results.

The different theories have been tested mainly in developed economies, while only in the last decade have several studies been done on emerging and developing economies. However, such research mainly or exclusively analyzes companies listed on the stock exchange, as they are the only companies for which data is available. Consequently, in most cases, those empirical results are attributable to the financial behavior of larger companies, which are also characterized by a greater awareness of the wide range of instruments available on financial markets. Those results, however, cannot explain the financial decisions of all the other companies, mainly small and medium-sized, present in that emerging economy. This gap in the literature is mainly due to a lack of data or difficulties related to data collection.

In this regard, the literature has suggested that the financial behavior of firms in these countries is still an open question capable of providing further and useful empirical evidence on the sustainability of the various theories.

Therefore, in the first place, the purpose of this paper was to investigate the determinants of the capital structure in an emerging economy, such as that of the Dominican Republic. For this purpose, we tested the theory of trade-off and that of the pecking order, using the main determinants suggested by the literature (size, profitability, assets tangibility and growth). Secondly, given that the Dominican Republic has introduced a series of tax incentives to encourage the establishment and development of businesses, we also investigated the impact of tax policy on the financial behavior of businesses, comparing the capital structure of the companies benefiting from the tax incentives with that of non-beneficiary companies.

In this regard, the results of our analysis offer some interesting results on the financial behaviour of firms, highlighting that tax incentives produce a different impact on each determining variable of the capital structure.

Although most empirical studies have found a positive association between taxation and financial leverage, the empirical results are often conflicting, also due to the different methods used to estimate the tax effect on the capital structure. This study overcomes the distorting problems associated with 
WSEAS TRANSACTIONS on BUSINESS and ECONOMICS DOI: $10.37394 / 23207.2021 .18 .71$

estimating the tax variable, being characterized by the fact that it uses the data from the tax returns of each company. The data cover the period 2012-2015 and were provided by the Ministry of Finance to the World Bank as part of a collaboration on the analysis of current fiscal policy. To assess the impact of each determinant and fiscal policy on the financial behaviour of firms, we used a fixed-effects (FE) estimation model.

The results show that the individual determinants of the capital structure, when significant, are attributable to both theories analyzed. However, the fiscal variable, in some cases, affects the financial behaviour of companies. In particular, the size positively influences the capital structure of the companies not benefiting from the tax incentives, while it tends to have a negative effect on the beneficiaries. The results of profitability are not conditioned by the fiscal variable and are more consistent with the trade-off theory. Assets tangibility has a positive impact on medium and long-term debt, in line with the forecasts of the two theories, but has a negative effect on the other variables investigated. Regarding growth, the results are conflicting or not significant but suggest that the fiscal variable affects the financial behaviour of firms. The overall results highlight that tax benefits have a significant and positive impact on total debt and short-term debt.

This paper can be relevant from several points of view.

To the best of our knowledge, this study is the first research investigating the financial behaviour of businesses of all sizes in the Dominican Republic. In this perspective, empirical findings are of primary interest for entrepreneurs and managers of Dominican companies to improve their financial decisions and for policymakers to assess the impact that tax policies have on the financial behaviour of companies.

Furthermore, the results provide an important contribution to the existing literature, as they highlight the capital structure of companies in an emerging economy and do not limit attention only to listed companies.
Alessandra Amendola, Marinella Boccia, Gianluca Mele, Luca Sensini Second, this study is one of the few that investigates the relationship between tax incentives and corporate capital structure, using data from corporate tax returns. In this perspective, the results allow a reliable representation of the aforementioned relationship, eliminating the possible distorting effect determined, in most of the previous studies, by the estimate of the fiscal variable.

\section{References}

[1]. Modigliani, F.; Miller, M.H. The cost of capital, corporation finance and the theory of investment, American Economic Review, 1958, 48, 261-297.

[2]. Modigliani, F.; Miller, M.H. Corporate income taxes and the cost of capital: a correction. American Economic Review, 1963, 53, 433-443.

[3]. Kraus, A.; Litzenberger, R.H. A statepreference model of optimal financial leverage The Journal of Finance, 1973, 28, 911-922.

[4]. Myers, C. The capital structure puzzle, The Journal of Finance, 1984, 39, 574592.

[5]. Myers, S.C.; Majluf N.S. Corporate financing and investment decisions when firms have information that investors do not have Journal of Financial Economics, 1984, 13, pp. 187-221.

[6]. Jensen, M. C. Agency costs of free cash flow, corporate finance, and takeovers, American Economic Review, 1986, 76, 323-329.

[7]. Baker, M.; Wurgler, J. Market timing and capital structure, The Journal of Finance, 2002, 57, 1-30.

[8]. Hovakimian, A. Are observed capital structures determined by equity market timing? Journal of Financial and Quantitative Analysis, 2006, 41, 221-243.

[9]. De Bie, T.; De Haan, L. Market timing and capital structure: Evidence for Dutch firms, De Economist, 2007, 2, 183-206. DOI: $10.1007 / \mathrm{s} 10645-007-9054-1$

[10]. Welch, I. Capital structure and stock returns Journal of Political Economy, 2004, 112, 106-131. 
WSEAS TRANSACTIONS on BUSINESS and ECONOMICS DOI: 10.37394/23207.2021.18.71

[11]. Bancel, F.; Mittoo, U. Crosscountry determinants of capital structure choice: A survey of European firms, Financial Management, 2004, 33, 103132.

[12]. de Jong, A.; Kabir, R.; Nguyen, T.T. Capital structure around the world: The roles of firm- and country-specific determinants, Journal of Banking \& Finance, 2008, 32, 1954-1969. DOI:10.1016/j.jbankfin.2007.12.034

[13]. Sensini, L. Factors Driving Capital Structure of Italian SME's, International Business Management, 2020, 14, 217225. DOI:10.36478/ibm.2020.217.225

[14]. Crnigoj, M.; Mramor, D. Determinants of capital structure in emerging european economies: evidence from slovenian firms Emerging Markets Finance Trade, 2009, 45, 72-89. DOI:10.2753/REE1540-496X450105

[15]. Wald, J.K. How firm characteristics affect capital structure: an international comparison, Journal of Financial Research, 1999, 22, 161-187.

[16]. Ardalan, K. Capital structure theory: Reconsidered, Research in International Business and Finance, 2017, 39, 696-710.

[17]. Myers, C. Capital structure, The Journal of Economic Perspectives, 2001, $15,81-102$.

[18]. Jensen, M.C.; Meckling, W.H. Theory of the firm: managerial behavior, agency costs and ownership structure, Journal of Financial Economics, 1976, 3, 305-360.

[19]. Cassar, G.; Holmes, S. Capital structure and financing of SMEs: Australian evidence, Accounting and Finance, 2003, 43, 123-47.

[20]. Chen, J.J. Determinants of capital structure of chinese-listed companies, Journal of Business Research, 2004, 57, 1341-135. DOI 10.1016/S01482963(03)00070-5

[21]. Deesomsak, R.; Paudyal, K.; Pescetto, G. The determinants of capital structure: evidence from the asia pacific region, Journal of Multinational Financial Management, 2004, 14, 387-405.

[22]. Abor, J. Agency theoretic determinants of debt level: evidence from
Ghana, Review of Accounting and Finance,2008, 7, 183-92. DOI 10.1108/14757700810874146

[23]. Psillaki, M.; Daskalakis, N. Are the determinants of capital structure country or firm specific? Small Business Economics, 2009, 33, 319-333. DOI 10.1007/s11187-008-9103-4

[24]. Degryse, H.; Goeij, P.; Kappert, P. The impact of firm and industry characteristics on small firms' capital structure, Small Business Economics, 2012, 38, 431-447.

[25]. Mateev, M.; Poutziouris, P., Ivanov, K. On the determinants of sme capital structure in central and eastern europe: a dynamic panel analysis, Research in International Business and Finance, 2013, 27, 28-51. DOI: 10.1016/j.ribaf.2012.05.002

[26]. Sbeti, W.M.; Moosa, I. Firmspecific factors as determinants of capital structure in the absence of taxes, Applied Financial Economics, 2012, 22, 209-213. DOI: 10.1080/09603107.2011.610738

[27]. Andres, C.; Cumming, D.; Karabiber, T.; Schweizerm D. Do markets anticipate capital structure decisions? feedback effects in equity liquidity, Journal of Corporate Finance, 2014, 27, 133-156.

DOI: 10.1016/j.jcorpfin.2014.02.006

[28]. Sensini, L. Capital Structure Determinants in Italian Sme's: An Empirical Study, ICAFR, 2017, 124-144.

[29]. Lucey, B.M., Zhang Q.Y Financial integration and emerging markets capital structure, Journal of Banking and Finance, 2011, 35, 1228-1238.

[30]. Safiullah, M. (2016). Board Governance, Ownership Structure and Financing Decisions in Emerging Market, Corporate Ownership and Control, 13 (3), pp. 355-365.

[31]. Ganiyu Y.O., Adelopo I., Rodionova Y., Samuel O.L. Capital Structure in Emerging Markets: Evidence from Nigeria, The European Journal of Applied Economics, 2018, 15, 74-90.

[32]. Vo, X.V. (2017). Determinants of Capital Structure in Emerging Markets: Evidence from Vietnam, Research in 
WSEAS TRANSACTIONS on BUSINESS and ECONOMICS

DOI: 10.37394/23207.2021.18.71

International Business and Finance, 40, pp. 105-113.

[33]. Ebrahim,

M.S., Girma, S., Shah, M.E., Williams,

J. Dynamic capital structure and political patronage: the case of Malaysia, International Review of Financial Analysis, 2014, 31, 117-128.

[34]. Malinić, D., Denčić-Mihajlov, D., Ljubenović E. , The Determinants of Capital Structure in Emerging Capital Markets: Evidence from Serbia, European Research Studies, 2013,16, 98-119.

[35]. Vo, X.V. , Determinants of capital structure in emerging markets: Evidence from Vietnam, Research in International Business and Finance, 2017, 40, 105-113.

[36]. Cosh, A.D.; Hughes, A. Size, financial structure and profitability, in Hughes A., Storey D.J. (Eds), Finance and the Small Firm, Routledge, London, 1994, 18-63.

[37]. Vos, E.; Jia-Yuh Yeh A.; Carter S.; Tagg S. The happy story of small business financing, Journal of Banking and Finance, 2007, 31, 2648-2672. DOI:10.1016/j.jbankfin.2006.09.011

[38]. Rajan, R.; Zingales, L. What do we know about capital structure? some evidence from international data, Journal of Finance, 1995, 50, 1421-1460.

[39]. Harris, M.; Raviv, A. The theory of capital structure, The Journal of Finance, 1991, 46, 297-355.

[40]. Graham, J.R. How big are the tax benefits of debt? Journal of Finance, 2000, $55,1901-1941$.

[41]. Booth, L.; Aivazian, L.; Demirguc-Kunt A.; Maksimovic V. Capital structures in developing countries, The Journal of Finance, 2001, 56, 87-130.

[42]. Fama, E.; French K. Testing tradeoff and pecking order predictions about dividends and debt. The Review of Financial Studies, 2002, 15, 1-33.

[43]. Faulkender, M.; Petersen, M.A. Does the source of capital affect capital structure?", Review of Financial Studies, 2006, 19, 45-79. DOI:10.1093/rfs/hhj003

[44]. Frank, M.; Goyal, V. Capital structure decisions: which factors are reliably important? Financial
Alessandra Amendola,

Marinella Boccia, Gianluca Mele, Luca Sensini

Management, 2009, 38, 1-37. DOI:10.1111/j.1755-053X.2009.01026.X

[45]. Chakraborty, I. Capital Structure in an Emerging Stock Market-Case of India, Reseach in International Business and finance, 2010, 24, 295-314. DOI 10.1016/j.ribaf.2010.02.001

[46]. Leary, M.; Roberts, M. The pecking order, debt capacity, and information asymmetry, Journal of Financial Economics, 2010, 95, 332-355. DOI 10.1016/j.jfineco.2009.10.009

[47]. Aggarwal, R. International differences in capital structure norms: an empirical study of large European companies, Management International Review, 1981, 21, 75-88.

[48]. Titman, S.; Wessels, R. The determinants of capital structure choice, Journal of Finance, 1988, 43, 1-19.

[49]. Bevan, A.A.; Danbolt, J. Capital structure and its determinants in the UK a decompositional analysis, Applied Financial Economics, 2002, 12 ,159-170.

[50]. Hall, G.; Hutchinson, P.; Michaelas N. Determinants of the Capital Structure of European SMEs, Journal of Business Finance and Accounting, 2004, 31, 711-728. DOI:10.1111/j.0306686X.2004.00554.X

[51]. La Rocca, M.; La Rocca, T., Gerace ,D.; Smark, C. Effect of diversification on capital structure, Accounting Finance, 2009, 49 799-826.

[52]. Ang, J.S. ; Chua, J.H.; McConnell, J.J. The administrative costs of corporate bankruptcy: a note Journal of Finance, 1982, 37, 219-226.

[53]. Sanchez, J.A.; Sensini, L. Small Firms and Demand for Credit. Evidence from Europe, ICAFR, 2017, 237-262.

[54]. Stiglitz, J.E., Andrew Weiss, A.. Credit Rationing in Markets with Imperfect Information, American Economic Review, 1981, 71, 393-410.

[55]. Beck, T.; Demirguc-Kunt, A. Small and medium-size enterprises: Access to finance as a growth constraint, Journal of Banking and Finance, 2006, 30, 29312943.

DOI:10.1016/j.jbankfin.2006.05.009

[56]. Beck, T.; de la Torre, A. The basic analytics of access to financial services 
Financial Market Institutions \&

Instruments, 2007, 16, 79-117.

DOI:10.1111/j.1468-0416.2007.00120.x

[57]. Mueller, A.; Sensini, L. Determinants of Financing Decisions of SMEs: Evidence from the Hotel Industry, International Journal of Business and Management, 2021, 16 (3), 117-127. DOI: 10.5539/ijbm.v16n3p117

[58]. Norton, E. Capital structure and small public firms, Journal of Business Venturing, 1991, 6, 287-303.;

[59]. Van der Wijst, N.; Thurik, R. Determinants of small firm debt ratios: An analysis of retail panel data. Small Business Economics, 1993, 5, 55-65.

[60]. Chittenden, F.; Hall, G.; Hutchinson, P. Small firm growth, access to capital markets and financial structure: Review of issues and an empirical investigation. Small Business Economics, 1996, 8, 59-67.

[61]. Michaelas, N.; Chittenden, F.; Poutzioris, P. Financial policy and capital structure choice in U.K. SMEs: Empirical evidence from company panel data. Small Business Economics, 1999, 12, 113-130.

[62]. Petersen, M.A.; Rajan, R.G. Does distance still matter? The information revolution in small business lending Journal of Finance, 2002, 57, 2533-2570.

[63]. Sogorb Mira, F. How SME uniqueness affects capital structure: Evidence from a 1994-1998 Spanish data panel. Small Business Economics, 2005, 25, 447-457. DOI:10.1007/s11187-0046486-8

[64]. La Porta, R; Lopez-de-Silanes, F; Shleifer, A.; W. R. Law and finance, Journal of Political Economy, 1998, 106, 1113-1155.

[65]. Amendola, A.; Boccia, M.; Mele, G., Sensini, L. Fiscal Policies and Performance: Evidence from Dominican Republic firms, Journal of Applied Finance \& Banking, 2020, 10, 299-313.

[66]. Amendola, A.; Boccia, M.; Mele, G; Sensini, L. Fiscal incentives and firm performance: evidence from the Dominican Republic, Policy Research Working Paper Series 8382, The World Bank, 2018.
Alessandra Amendola, Marinella Boccia, Gianluca Mele, Luca Sensini

[67] Nguyen, H.M.; Vuong, T.H.G.; Nguyen, T.H.; Wu, Y.C.; Wong, W.K. Sustainability of Both Pecking Order and Trade-Off Theories in Chinese Manufacturing Firms, Sustainability, 2020, 12, 3883. DOI: 10.3390/su12093883

[68]. Ramli, N.A.; Latan, H.; Solovida, G.T. Determinants of capital structure and firm financial performance-A PLS-SEM approach: Evidence from Malaysia and Indonesia, The Quarterly Review of Economics and Finance, 2019, 71, 148160. DOI:10.1016/j.qref.2018.07.001

[69]. Rao, P.; Kuma,r S.; Madhavan, V. A study on factors driving the capital structure decisions of small and medium enterprises (SMEs) in India, IIMB Management Review, 2019, 31, 37-50.

[70]. LaLonde, R.J. Evaluating the Econometric Evaluations of Training Programs with Experiment Data, American Economic Review, 1986, 76, 604-620.

[71]. Chai, J., Goyal, R., Tax concessions and Foreign Direct Investment in the Eastern Caribbean Currency Union, IMF, WP08/257, 2008.

[72]. Chai, J., and R. Goyal Tax Concessions and Foreign Direct Investment in the Eastern Caribbean Currency Union," in R. Sahay, D.O. Robinson and P. Cashin (eds), The Caribbean: From Vulnerability to Sustained Growth, IMF, 2006,258-284.

[73]. Sosa, S. Tax Incentives and Investment in the Eastern Caribbean, IMF, Working Paper 06/23, 2006.

[74]. Nassa,r K. , Corporate Income Tax Competition in the Caribbean, IMF, Working Paper 08/77, 2008.

[75]. Schipke, A., Cebotari, A., Thacker, N. , The Easter Caribbean Economic and Currency Union. Macroeconomics and Financial System, IMF, 2013.

[76]. 64. Wooldridge, J. Econometric Analyis of Cross Section and Panel Data. Secon Edition MIT Press, Cambridge, US, 2010. 
[77]. Ramsey, J. B. , "Tests for Specification Errors in Classical Linear Least Squares Regression Analysis". Journal of the Royal Statistical Society, Series B, 1969, 31 , 350-371.

[78]. Hausman, J. A. Specification tests in econometrics. Econometrica, 1978, 46, $1251-1271$

[79]. Deesomsak, R., Paudyal, K., Pescetto, G., The determinants of capital structure: evidence from the asia pacific region, Journal of Multinational Financial Management, 2004, 14, 387405.

[80]. Oino, I, Ukaegbu, B. , The impact of profitability on capital structure and speed of adjustment: An empirical examination of selected firms in Nigerian Stock Exchange, Research in International Business and Finance, 2015, 35, 111-121.

[81]. - Salawu, R.O., Agboola

A.A. (2008), The determinants of capital structure of large non-financial listed firms in Nigeria, The International Journal of Business and Finance Research, 2 (2), pp. 75-84.

[82]. Vo, X.V., Determinants of capital structure in emerging markets: Evidence from Vietnam, Research in International Business and Finance, 2017, 40, 105-113.

[83]. Wiwattanakantang, Y. , An empirical study on the determinants of the capital structure of thai firms, PacificBasin Finance Jornal, 1999, 7, 371-403.
Alessandra Amendola, Marinella Boccia, Gianluca Mele, Luca Sensini

[84] Karadeniz, E., Kandir, S.Y., Balcil ar M., Onal Y., Determinants of capital structure: evidence from Turkish lodging companies, International Journal of Contemporary Management, 2009, 21, 594-609.

[85]. Tongkong, S. , Key factors influencing capital structure decision and its speed of adjustment of Thai listed real estate companies, Procedia-Social and Behavioral Sciences, 2012, 40 , 716-720.

[86]. Chauhan, G.S. , Reconciling theory and evidences for corporate financing in India, Journal of Emerging Market Finance, 2016, 15 , 295-309.

[87]. Komera, S., Lukose, J. , Capital structure choice, information asymmetry, and debt capacity: evidence from India, Journal of Economics and Finance, 2015, 39, 807-823.

[88]. Bandyopadhyay, A., Barua, M.N., Factors determining capital structure and corporate performance in India: studying the business cycle effects, Quarterly Review of Economics and Finance, 2016, 61, 160- 


\section{Creative Commons Attribution License 4.0 (Attribution 4.0 International, CC BY 4.0)}

This article is published under the terms of the Creative Commons Attribution License 4.0

https://creativecommons.org/licenses/by/4.0/deed.en_US 